\title{
EFFECTS OF ROSEMARY (ROSMARINUS OFFICINALIS L.) LEAF EXTRACT ON ANGULAR CHEILITIS INDUCED BY STAPHYLOCOCCUS AUREUS AND CANDIDA ALBICANS IN MALE WISTAR RATS
}

\author{
SUMINTARTI ${ }^{1}$, NURUL FATIMASARI S. $^{1}$, ANDI S. HAJRAH-YUSUF ${ }^{2}$, MUHAMMAD RUSLIN ${ }^{2 *}$ \\ ${ }^{1}$ Department of Oral Medicine, Faculty of Dentistry, Hasanuddin University, Makassar, 90245, Indonesia. ${ }^{2}$ Department of Oral and \\ Maxillofacial Surgery, Faculty of Dentistry, Hasanuddin University, Makassar, 90245, Indonesia. Email: mruslin@unhas.ac.id
}

Received: 20 June 2018, Revised and Accepted: 25 August 2018

\begin{abstract}
Objective: The study aimed to determine the effect of rosemary (Rosmarinus officinalis L.) leaf extract on healing angular cheilitis induced by Staphylococcus aureus and Candida albicans in male Wistar rats.

Methods: We assessed 24 male Wistar rats that were divided into four groups: The first group was induced by $S$. aureus and given rosemary leaf extract, the second group was induced by $S$. aureus and given gentamicin, the third group was induced by $C$. albicans and given rosemary leaf extract, and the fourth group was induced by $C$. albicans and given miconazole. All rats in each group were treated, and wound length and erythema were observed for 7 days.
\end{abstract}

Results: The average wound length on the $7^{\text {th }}$ day was $0.00 \pm 0.0 \mathrm{~mm}$ in the first group, $0.29 \pm 0.4 \mathrm{~mm}$ in the second group, $0.00 \pm 0.0 \mathrm{~mm}$ in the third group, and $0.25 \pm 0.2 \mathrm{~mm}$ in the fourth group. Statistical analysis demonstrated significant differences in wound length for each treatment group.

Conclusion: Rosemary leaf extract has a healing effect on angular cheilitis induced by S. aureus and C. albicans in male Wistar rats.

Keywords: Cheilitis, Wistar rats, Wound.

(c) 2018 The Authors. Published by Innovare Academic Sciences Pvt Ltd. This is an open access article under the CC BY license (http://creativecommons. org/licenses/by/4. 0/) DOI: http://dx.doi.org/10.22159/ijap.2018.v10s1.39

\section{INTRODUCTION}

Global "Back to Nature" trends have increased public awareness of organic food production and healthier, safer, and cheaper raw materials using natural ingredients [1]. Various types of plants are extremely beneficial, particularly as herbal medicines. Indonesia is the second most biodiverse country in the world, with approximately 30,000 species of plants, including approximately 2500 species with medicinal properties [1], demonstrating that Indonesia is an excellent source for plants that are useful as herbal medicines.

One type of plant that is used as herbal medicine is an ornamental plant [2]. Rosemary (Rosmarinus officinalis L.) not only is a decorative plant but also contains medicinal ingredients in the form of phytochemicals, such as flavonoids, phenolic acid, tannic acid, saponin, carnosic acid, borneol, and essential oils which are beneficial to human health $[3,4]$. Rosemary has approximately $0.5-2.5 \%$ of essential oils containing monoterpene with camphor (15-25\%), cineole $(15-50 \%), \alpha$-pinene $\quad(10-25 \%)$, camphene (5.2-8.6\%), and borneol (3.2-7.7\%). The flavonoids that are known to be contained in rosemary plants include diosmin, diosmetin, genkwanin, luteolin, and apigenin. Rosemary also contains phenolic acids including rosmarinic acid, caffeic acid, and phenolic compounds as well as tricyclic diterpenes such as carnosol and labiatic acids [5].

Previous research has shown that rosemary is an effective antioxidant, anti-inflammatory, anticancer, antiulcer, antidiabetic, antiviral, antifungal, and antibacterial agent, particularly against Gram-positive bacteria, such as Staphylococcus aureus and Enterococcus faecalis, and Gram-negative bacteria, such as Escherichia coli $[3,6-8]$. However, until now, research exploring the effect of rosemary in treating specific diseases such as angular cheilitis has been scant.
Angular cheilitis, also known as perleche or angular cheilitis, is a lesion marked with fissures and cracks in the corner of the mouth in addition to reddish ulceration accompanied by burning sensation, pain, and dryness [9]. Angular cheilitis is one of the most common types of oral lesions and responsible for $0.7-3.8 \%$ of oral mucosal lesions in adults and $0.2-15.1 \%$ in children. The treatment of angular cheilitis highly depends on the cause of the infection. An antifungal ointment, such as miconazole $2 \%$ applied topically to the corner of the mouth, is often used as a healing agent. Unfortunately, the side effects of this medicine are unavoidable [10-13]. Herbal medicine is believed to have minimal side effects; thus, rosemary leaf extract may be a good choice for the treatment of angular cheilitis.

The aim of this study is to determine the effect of rosemary leaf extract as an alternative treatment of angular cheilitis.

\section{MATERIALS AND METHODS}

\section{Materials}

This was an experimental laboratory study with a post-test only control group design conducted at the Phytochemistry Laboratory and Biopharmaceutical Laboratory, Faculty of Pharmacy, Hasanuddin University, Indonesia, between May and June 2017. For the present study, we used 24 male Wistar rats (Rattus novergicus) induced by S. aureus and Candida albicans. The rats were divided into four treatment groups and sampled using simple random sampling. Group $1(n=6)$ was induced with S. aureus and given rosemary leaf extract, Group 2 $(\mathrm{n}=6)$ was induced with $S$. aureus and given gentamicin, Group $3(\mathrm{n}=6)$ was induced with $C$. albicans and given rosemary leaf extract, and Group $4(\mathrm{n}=6)$ was induced with $C$. albicans and given miconazole. The study was conducted under the approval of the Medical Ethics Board (399/H4.8.4.5.31/PP36-KOMETIK/2017), Faculty of Medicine, Universitas Hasanuddin, Makassar, Indonesia. 
Rosemary leaf extract was obtained by extrication using a maceration method with $70 \%$ ethanol and evaporation using a rotary evaporator to achieve a viscous extract. The selected leaves were old, fresh, dark green, and intact. Next, the viscous extract was prepared in a $100 \%$ concentration by mixing equal parts of extract and sodium carboxymethyl cellulose 1\%. Inocula for S. aureus (ATCC 25923) and C. albicans were obtained from the Microbiology Laboratory, Faculty of Pharmacy, Universitas Hasanuddin.

Cuts were made on both the corners of the mouth of male Wistar rats by mutually pulling between the upper and lower lips to make the fissure wound. This method resulted in invisible injuries requiring tweezers to aid in making the wound due to the elasticity in the corners of the mouth of the rats. The wounds were 4-mm long to allow the bacteria and fungi to invade quickly. Next, induction was performed using a sterile spherical OSE with an inoculum of $S$. aureus in Groups 1 and 2 and of $C$. albicans in Groups 3 and 4. The wound was left untreated for $24 \mathrm{~h}$ to incur bacterial and fungal growth in both the corners of the mouth. After $24 \mathrm{~h}$, Groups 1 and 3 were given rosemary leaf extract, Group 2 was given gentamicin, and Group 4 was given miconazole; all treatments were applied topically. Wound length and erythema were observed in each group for 7 days.

Wilcoxon test was performed to determine the significance of the treatment effect in the sample groups. Normality tests were performed before the statistical tests. Furthermore, Mann-Whitney U-test was performed to determine whether the treatment groups had the same or different effects.

\section{RESULTS}

The statistical test was conducted to determine the significance of the effect of the treatment on the sample. Before statistical tests, normality tests were performed using Shapiro-Wilk test. Based on Shapiro-Wilk normality test results, some abnormal samples were observed $(\mathrm{p}<0.05$, Table 1). Due to data abnormalities, an alternative test (repeatedmeasures ANOVA or Friedman test) was performed (Table 2). Wilcoxon test aimed to determine which treatment groups experienced significant or non-significant changes in wound length between the $1^{\text {st }}$ and following days (Tables 3-6). Furthermore, to view the treatment groups having the same or different effects with one another, the MannWhitney U-test was performed (Tables 7 and 8).

As shown in Table 1, Group 1 had the greatest mean decrease in wound length, followed by Group 3 (C. albicans, rosemary leaf extract). The groups using rosemary leaf extract had a better healing effect than the control groups using gentamicin and miconazole, demonstrating that rosemary leaf extract had a healing effect on angular cheilitis.
Based on the results of the present study, rosemary leaf extract has a healing effect on angular cheilitis induced by $S$. aureus and $C$. albicans in male Wistar rats. Rosemary leaf extract contains essential oils, flavonoids, phenolic acid, tricyclic diterpene, and ursolic acid, which potentially have antibacterial, antifungal, antiviral, antioxidant, antiinflammatory, anticancer, antiulcer, and antidiabetic characteristics. Physical observation on day 0 for all four groups showed bacterial infections in Groups 1 and 2, which were indicated by tissue damage in the area around the lesion, and fungal infections in Groups 3 and 4, which were characterized by severe tissue damage around the lesion. Fungal infection wounds were more severe than bacterial infection wounds. On the $1^{\text {st }}$ day, all groups underwent an inflammatory phase, which is the defense reaction of the live tissue against all forms of wound infections. This involves the functioning of the blood and blood vessels, lymphatic vessels, nerves, fluids, and cells around the wound. The inflammatory reaction stage of the infection is due to the introduction of a number of pathogenic microorganisms, namely S. aureus and C. albicans, into the wound area. Numerous pathogenic microorganisms enter the tissues through the open areas of the wound [13].

\section{DISCUSSION}

Group 1, induced by $S$. aureus and given rosemary leaf extract, showed the fastest healing from angular cheilitis wounds. This is in agreement with Moreno et al. who demonstrated that rosemary extract was an effective antibacterial agent against Gram-positive bacteria such as $S$. aureus. Based on their research, rosemary leaf extract contains carnosic acid and carnosols that have a major antibacterial role against S. aureus [3].

A study by Hernandez found that rosemary leaves are high in antioxidants due to the presence of carnosic acid [15], and Moreno et al. suggested that carnosic acid has intracellular antibacterial activity against $S$. aureus. Carnosic acid concentrations that are toxic to S. aureus bacteria are non-toxic to macrophages. In their study of in vivo antibacterial from rosemary extract, Barni et al. showed a considerable effect of carnosic acid on $S$. aureus in two trials of skin infections in mice [3].

Other major ingredients in rosemary leaves, such as essential oils, flavonoids, and ursolic acid, have important roles in wound healing. Essential oils contain phenol and chavicol, which are useful as antimicrobials, antibacterial, and disinfectants. It can clean the wound and prevent infection, thereby accelerating to the end of the inflammatory phase in the wound healing process [16]. In a study examining the anti-inflammatory effect of rosmarinic acid and rosemary leaf extract in rat models of local and systemic inflammation, Rocha et al. identified rosmarinic acid in rosemary leaf extract to possess anti-inflammatory and antioxidant qualities. Based on these

Table 1: Average length of the angular cheilitis wound

\begin{tabular}{|c|c|c|c|c|c|c|c|c|}
\hline Treatment groups & $\begin{array}{l}\text { Day } 0 \\
(\text { mean } \pm S D)\end{array}$ & $\begin{array}{l}\text { Day } 1 \\
(\text { mean } \pm \text { SD) }\end{array}$ & $\begin{array}{l}\text { Day } 2 \\
(\text { mean } \pm S D)\end{array}$ & $\begin{array}{l}\text { Day } 3 \\
(\text { mean } \pm S D)\end{array}$ & $\begin{array}{l}\text { Day } 4 \\
(\text { mean } \pm S D)\end{array}$ & $\begin{array}{l}\text { Day } 5 \\
(\text { mean } \pm S D)\end{array}$ & $\begin{array}{l}\text { Day } 6 \\
(\text { mean } \pm S D)\end{array}$ & $\begin{array}{l}\text { Day } 7 \\
(\text { mean } \pm S D)\end{array}$ \\
\hline Group 1 & $4.00 \pm 0.0$ & $2.95 \pm 0.1$ & $2.45 \pm 0.2$ & $1.79 \pm 0.3$ & $1.20 \pm 0.4$ & $0.54 \pm 0.4$ & $0.16 \pm 0.2$ & $0.00 \pm 0.0$ \\
\hline Group 2 & $4.00 \pm 0.0$ & $3.45 \pm 0.4$ & $3.20 \pm 0.5$ & $2.75 \pm 0.5$ & $2.12 \pm 0.4$ & $1.16 \pm 0.6$ & $0.66 \pm 0.7$ & $0.29 \pm 0.4$ \\
\hline Group 3 & $4.00 \pm 0.0$ & $3.25 \pm 0.1$ & $2.70 \pm 0.2$ & $2.16 \pm 0.5$ & $1.54 \pm 0.6$ & $1.00 \pm 0.5$ & $0.33 \pm 0.3$ & $0.00 \pm 0.0$ \\
\hline Group 4 & $4.00 \pm 0.0$ & $3.87 \pm 0.2$ & $3.41 \pm 0.2$ & $2.75 \pm 0.3$ & $2.25 \pm 0.2$ & $1.29 \pm 0.5$ & $0.66 \pm 0.4$ & $0.25 \pm 0.2$ \\
\hline
\end{tabular}

Table 2: Average length of the angular cheilitis wound and Friedman test results

\begin{tabular}{|c|c|c|c|c|c|c|c|c|c|}
\hline Treatment groups & $\begin{array}{l}\text { Day } 0 \\
(\text { mean } \pm S D)\end{array}$ & $\begin{array}{l}\text { Day } 1 \\
(\text { mean } \pm S D)\end{array}$ & $\begin{array}{l}\text { Day } 2 \\
(\text { mean } \pm S D)\end{array}$ & $\begin{array}{l}\text { Day } 3 \\
(\text { mean } \pm S D)\end{array}$ & $\begin{array}{l}\text { Day } 4 \\
(\text { mean } \pm S D)\end{array}$ & $\begin{array}{l}\text { Day } 5 \\
(\text { mean } \pm S D)\end{array}$ & $\begin{array}{l}\text { Day } 6 \\
(\text { mean } \pm S D)\end{array}$ & $\begin{array}{l}\text { Day } 7 \\
(\text { mean } \pm S D)\end{array}$ & p value* \\
\hline Group 1 & $4.00 \pm 0.0$ & $2.95 \pm 0.1$ & $2.45 \pm 0.2$ & $1.79 \pm 0.3$ & $1.20 \pm 0.4$ & $0.54 \pm 0.4$ & $0.16 \pm 0.2$ & $0.00 \pm 0.0$ & 0.00 \\
\hline Group 2 & $4.00 \pm 0.0$ & $3.45 \pm 0.4$ & $3.20 \pm 0.5$ & $2.75 \pm 0.5$ & $2.12 \pm 0.4$ & $1.16 \pm 0.6$ & $0.66 \pm 0.7$ & $0.29 \pm 0.4$ & 0.00 \\
\hline Group 3 & $4.00 \pm 0.0$ & $3.25 \pm 0.1$ & $2.70 \pm 0.2$ & $2.16 \pm 0.5$ & $1.54 \pm 0.6$ & $1.00 \pm 0.5$ & $0.33 \pm 0.3$ & $0.00 \pm 0.0$ & 0.00 \\
\hline Group 4 & $4.00 \pm 0.0$ & $3.87 \pm 0.2$ & $3.41 \pm 0.2$ & $2.75 \pm 0.3$ & $2.25 \pm 0.2$ & $1.29 \pm 0.5$ & $0.66 \pm 0.4$ & $0.25 \pm 0.2$ & 0.00 \\
\hline
\end{tabular}

*Friedman test, $\mathrm{p}<0.05$ 
Table 3: Changes in wound length between the $1^{\text {st }}$ and following days in Group 1

\begin{tabular}{|c|c|c|c|c|c|c|c|c|}
\hline \multirow[t]{2}{*}{ Treatment groups } & \multicolumn{8}{|c|}{ Treatment groups } \\
\hline & Day 0 & Day 1 & Day 2 & Day 3 & Day 4 & Day 5 & Day 6 & Day 7 \\
\hline Day 0 & - & 0.026 & 0.026 & 0.027 & 0.027 & 0.026 & 0.026 & 0.014 \\
\hline Day 1 & & - & 0.026 & 0.027 & 0.026 & 0.026 & 0.020 & 0.026 \\
\hline Day 2 & & & - & 0.026 & 0.026 & 0.027 & 0.026 & 0.026 \\
\hline Day 3 & & & & - & 0.023 & 0.024 & 0.027 & 0.027 \\
\hline Day 4 & & & & & - & 0.023 & 0.026 & 0.027 \\
\hline Day 5 & & & & & & - & $0.059^{*}$ & $0.059 *$ \\
\hline Day 6 & & & & & & & - & $0.102 *$ \\
\hline Day 7 & & & & & & & & - \\
\hline
\end{tabular}

Table 4: Changes in wound length between the $1^{\text {st }}$ and following days in Group 2

\begin{tabular}{|c|c|c|c|c|c|c|c|c|}
\hline \multirow[t]{2}{*}{ Treatment groups } & \multicolumn{8}{|c|}{ Treatment groups } \\
\hline & Day 0 & Day 1 & Day 2 & Day 3 & Day 4 & Day 5 & Day 6 & Day 7 \\
\hline Day 0 & - & 0.041 & 0.027 & 0.026 & 0.026 & 0.027 & 0.027 & 0.026 \\
\hline Day 1 & & - & 0.034 & 0.026 & 0.027 & 0.026 & 0.027 & 0.026 \\
\hline Day 2 & & & - & 0.026 & 0.027 & 0.026 & 0.027 & 0.027 \\
\hline Day 3 & & & & - & 0.027 & 0.027 & 0.027 & 0.027 \\
\hline Day 4 & & & & & - & 0.027 & 0.026 & 0.026 \\
\hline Day 6 & & & & & & & - & $0.066^{*}$ \\
\hline Day 7 & & & & & & & & - \\
\hline
\end{tabular}

Table 5: Changes in wound length between the $1^{\text {st }}$ and following days in Group 3

\begin{tabular}{|c|c|c|c|c|c|c|c|c|}
\hline \multirow[t]{2}{*}{ Treatment groups } & \multicolumn{8}{|c|}{ Treatment groups } \\
\hline & Day 0 & Day 1 & Day 2 & Day 3 & Day 4 & Day 5 & Day 6 & Day 7 \\
\hline Day 0 & - & 0.024 & 0.027 & 0.027 & 0.027 & 0.028 & 0.026 & 0.014 \\
\hline Day 1 & & - & 0.026 & 0.027 & 0.027 & 0.027 & 0.027 & 0.024 \\
\hline Day 2 & & & - & 0.026 & 0.027 & 0.026 & 0.027 & 0.027 \\
\hline Day 3 & & & & - & 0.026 & 0.027 & 0.027 & 0.027 \\
\hline Day 4 & & & & & - & 0.027 & 0.027 & 0.027 \\
\hline Day 5 & & & & & & - & 0.027 & 0.028 \\
\hline Day 6 & & & & & & & - & $0.063^{*}$ \\
\hline Day 7 & & & & & & & & - \\
\hline
\end{tabular}

Table 6: Changes in wound length between the $1^{\text {st }}$ and following days in group 4

\begin{tabular}{|c|c|c|c|c|c|c|c|c|}
\hline \multirow[t]{2}{*}{ Treatment groups } & \multicolumn{8}{|c|}{ Treatment groups } \\
\hline & Day 0 & Day 1 & Day 2 & Day 3 & Day 4 & Day 5 & Day 6 & Day 7 \\
\hline Day 0 & - & 0.180 & 0.026 & 0.026 & 0.026 & 0.027 & 0.027 & 0.026 \\
\hline Day 1 & & - & 0.026 & 0.026 & 0.027 & 0.027 & 0.027 & 0.027 \\
\hline Day 2 & & & - & 0.023 & 0.027 & 0.027 & 0.027 & 0.026 \\
\hline Day 3 & & & & - & 0.024 & 0.027 & 0.027 & 0.024 \\
\hline Day 4 & & & & & - & 0.027 & 0.027 & 0.026 \\
\hline Day 5 & & & & & & - & 0.024 & 0.027 \\
\hline Day 6 & & & & & & & - & 0.026 \\
\hline Day 7 & & & & & & & & - \\
\hline
\end{tabular}

studies, rosmarinic acid demonstrated good anti-inflammatory activity, including antioxidant properties, inhibition of neutrophil activity, inhibition of MMP-9 activity, and modulation of NF-jB. The possible molecular mechanisms of rosmarinic acid might be mediated by the suppression of ERK, JNK, and p38 phosphorylation [17]. Therefore, rosemary leaf extract can accelerate the wound healing process [18].

According to Table 7, groups induced with S. aureus exhibited significant differences between treatment with rosemary leaf extract (group 1) and gentamicin (group 2) on the $2^{\text {nd }}, 3^{\text {rd }}$, and $4^{\text {th }}$ days. The effective difference between Groups 1 and 2 might be due to the active ingredients contained in the rosemary leaf extract that possesses antibacterial and anti-inflammatory characteristics, while gentamicin only acts as an antibacterial. According to Table 8, groups induced with C. albicans showed a significant difference between treatment with rosemary leaf extract (Group 3) and miconazole (Group 4) on the $1^{\text {st }}$, $2^{\text {nd }}, 3^{\text {rd }}$, and $4^{\text {th }}$ days. The effective difference between Groups 3 and 4 may be due to the active ingredients contained in the rosemary leaf 
Table 7: Average wound length and results of Mann-Whitney $U$-test

\begin{tabular}{|c|c|c|c|c|c|c|c|c|}
\hline Treatment groups & $\begin{array}{l}\text { Day } 0 \\
(\text { mean } \pm S D)\end{array}$ & $\begin{array}{l}\text { Day } 1 \\
(\text { mean } \pm S D)\end{array}$ & $\begin{array}{l}\text { Day } 2 \\
\text { (mean } \pm S D)\end{array}$ & $\begin{array}{l}\text { Day } 3 \\
\text { (mean } \pm S D)\end{array}$ & $\begin{array}{l}\text { Day } 4 \\
(\text { mean } \pm S D)\end{array}$ & $\begin{array}{l}\text { Day } 5 \\
\text { (mean } \pm S D)\end{array}$ & $\begin{array}{l}\text { Day } 6 \\
(\text { mean } \pm S D)\end{array}$ & $\begin{array}{l}\text { Day } 7 \\
(\text { mean } \pm S D)\end{array}$ \\
\hline Group 1 & $4.00 \pm 0.0$ & $2.95 \pm 0.1$ & $2.45 \pm 0.2$ & $1.79 \pm 0.3$ & $1.20 \pm 0.4$ & $0.54 \pm 0.4$ & $0.16 \pm 0.2$ & $0.00 \pm 0.0$ \\
\hline Group 2 & $4.00 \pm 0.0$ & $3.45 \pm 0.4$ & $3.20 \pm 0.5$ & $2.75 \pm 0.5$ & $2.12 \pm 0.4$ & $1.16 \pm 0.6$ & $0.66 \pm 0.7$ & $0.29 \pm 0.4$ \\
\hline p value* & 1.000 & 0.065 & 0.026 & 0.009 & 0.004 & 0.132 & 0.240 & 0.180 \\
\hline
\end{tabular}

*Mann-Whitney $U$-test, $\mathrm{p}<0.05$

Table 8: The average wound length and results of Mann-Whitney $U$-test

\begin{tabular}{|c|c|c|c|c|c|c|c|c|}
\hline Treatment groups & $\begin{array}{l}\text { Day } 0 \\
(\text { mean } \pm S D)\end{array}$ & $\begin{array}{l}\text { Day } 1 \\
\text { (mean } \pm S D)\end{array}$ & $\begin{array}{l}\text { Day } 2 \\
\text { (mean } \pm S D)\end{array}$ & $\begin{array}{l}\text { Day } 3 \\
(\text { mean } \pm S D)\end{array}$ & $\begin{array}{l}\text { Day } 4 \\
\text { (mean } \pm \text { SD) }\end{array}$ & $\begin{array}{l}\text { Day } 5 \\
(\text { mean } \pm S D)\end{array}$ & $\begin{array}{l}\text { Day } 6 \\
\text { (mean } \pm S D)\end{array}$ & $\begin{array}{l}\text { Day } 7 \\
\text { (mean } \pm \text { SD) }\end{array}$ \\
\hline Group 3 & $4.00 \pm 0.0$ & $3.25 \pm 0.1$ & $2.70 \pm 0.2$ & $2.16 \pm 0.5$ & $1.54 \pm 0.6$ & $1.00 \pm 0.5$ & $0.33 \pm 0.3$ & $0.00 \pm 0.0$ \\
\hline Group 4 & $4.00 \pm 0.0$ & $3.87 \pm 0.2$ & $3.41 \pm 0.2$ & $2.75 \pm 0.3$ & $2.25 \pm 0.2$ & $1.29 \pm 0.5$ & $0.66 \pm 0.4$ & $0.25 \pm 0.2$ \\
\hline $\mathrm{p}$ value* & 1.000 & 0.002 & 0.004 & 0.041 & 0.026 & 0.485 & 0.240 & 0.065 \\
\hline
\end{tabular}

*Mann-Whitney $U$-test, $P<0.05$

extract that possesses antifungal and anti-inflammatory characteristics, while miconazole only acts as an antifungal. This is consistent with the results of a study by Biljana observing antimicrobial and antioxidant properties of rosemary and sage essential oils, demonstrating that the essential oils contained in rosemary have a significant role in antifungal activity [19].

Based on the order of effectiveness in the wound healing process, the largest effect of rosemary leaf extract treatment was in Group 1, induced by $S$. aureus, followed by Group 3, induced by $C$. albicans. The most effective control group was Group 2, treated with gentamicin, followed by Group 4, treated with miconazole, supporting the hypothesis that rosemary leaf extract is more effective against wound healing infections caused by $S$. aureus than by $C$. albicans.

\section{CONCLUSION}

From the results of the present study, it can be concluded that rosemary leaf extract has a positive effect on wound healing of angular cheilitis induced by $S$. aureus and $C$. albicans in male Wistar rats. Rosemary leaf extract was more effective against wound healing of angular cheilitis induced by $S$. aureus than that by $C$. albicans.

\section{ACKNOWLEDGMENT}

Authors would like to thank all staff from Laboratory and Biopharmaceutical who have helped us in preparing the sample used in this research.

\section{CONFLICTS OF INTEREST}

The authors have no conflicts of interest.

\section{REFERENCES}

1. Dalimartha S, Adrian F. Scientific Facts About Fruits and Vegetables. Jakarta: Penebar Swadaya Grup; 2013.

2. Mursito B, Heru P. Efficiency of Ornamental Plants as Drugs. Jakarta: Penebar Swadaya Grup; 2011.

3. Moreno S, Sana AM, Gaya M, Barni MV, Castro OA, van Baren C. Rosemary compounds as nutraceutical health products. In: El-Samragy Y, editor. Food Additives. Rijeka: Intech-open Science; 2012. p.157-74.
4. Quattrocchi U. World Dictionary of Medicinal and Poisonous Plants: Common Names, Eponyms, Synonyms and Etymology. Florida: CRC Press; 2012. p. 3960.

5. Kuhn MA, Winston D. Herbal Therapy and Supplements: A Scientific and Traditional Approach. New York: Wolters Kluwer Health/ Lippincott Williams and Wilkins; 2008. p. 380-3.

6. Chooi OH. Spices: Food and Medicinal Benefits. Kuala Lumpur: PrinAD SDN. BHD; 2008. p. 186-7.

7. Safitri D, Sukandar EY, Fidrianny I, Susanto E. The study of antifungal activity from indigenous plants from Indonesia: An in vitro study. Asian J Pharm Clin Res 2017; 10:196-201.

8. Sukandar EY, Safitri D, Susanto E, Fidrianny I. Evaluation of antifungal activity of a 3-extract formulation in topical dosage form and its safety aspect. Asian J Pharm Clin Res 2016;9 Suppl 2:206-10.

9. Fajriani F. Management of angular cheilitis in children. J Dentomaxillofac Sci 2017;2:1-3.

10. Mahreen S, Raheela F, Anan. S. Angular cheilitis: Case reports and literature review. Pak Oral Dent J 2014;34:597-9.

11. Ali Y, Zohra N, Erni M. Efficacy of angular cheilitis therapy in department of oral medicine, faculty of dentistry Hasanuddin university based on causative principle. Makassar Dent J 2013;2:1-3.

12. Crispian S. Oral and Maxillofacial Medicine: The Basis of Diagnosis and Treatment. Edinburgh, New York: Churchill Livingstone, Elsevier; 2013. p. 147-9.

13. Torello ML, Lawrence CP, Roy SR. Oral Diseases: Textbook and Atlas. New York: Springer; 2012. p. 22.

14. Asep SA. Injury, inflammation, and recovery. J Entropi 2014:9;729-38.

15. Hernández-Hernández E, Ponce-Alquicira E, Jaramillo-Flores ME, Guerrero Legarreta I. Antioxidant effect rosemary (Rosmarinus officinalis L.) and oregano (Origanum vulgare L.) extracts on TBARS and colour of model raw pork batters. Meat Sci 2009;81:410-7.

16. Aliefia DK, Umi K, Ika SR. Effect of gel betel Linn extract (Piper betle linn.) to number of fibroblasts IIA burns degree in white rats (Rattus norvegicus) galur wistar. Majalah Kesehatan FKUB 2015;2:16-28.

17. Das S, Mandal SK. Current developments on anti-inflammatory natural medicines. Asian J Pharm Clin Res 2018;11:61-5.

18. Rocha J, Eduardo-Figueira M, Barateiro A, Fernandes A, Brites D, Bronze R, et al. Anti-inflammatory effect of rosmarinic acid and an extract of Rosmarinus officinalis in rat models of local and systemic inflammation. Basic Clin Pharmacol Toxicol 2015;116:398-413.

19. Bozin B, Mimica-Dukic N, Samojlik I, Jovin E. Antimicrobial and antioxidant properties of rosemary and sage (Rosmarinus officinalis L. And Salvia officinalis L. Lamiaceae) essential oils. J Agric Food Chem 2007;55:7879-85. 